Simon Obwatho, Ph.D., Africa Nazarene University (Nairobi, Kenya)

\title{
ADVANCING STRATEGIC PLANNING FOR FAMILIES: REFACING FAMILY PLANNING AND FAMILY ECONOMICS
}

\begin{abstract}
The concept of strategic thinking has failed to take its due place among families. While, organizations continue to execute robust and increasingly complex strategic plans, families endure in the tradition of extemporary, ad hoc short term and uncalculated long term decisions. This paper gives a blow-by-blow account of the historical and contemporary developments that have led to body of knowledge and general presuppositions concerning family planning as widely understood today. It sustains the opinion that the concept of strategic planning needs to be advanced among families. Meanwhile, this paper opines that "family planning" as is currently regarded, needs to be reviewed in terms of naming and disciplinary content to create a fit within its due scope under healthcare.
\end{abstract}

Keywords: family planning, strategic family planning, strategic thinking, vision statement, mission statement, family situation analysis, gap analysis, strategic implementation, family strategic success, economic and wealth concern, economic value, family support system, family economy, economics of marriage, economics of relationships, economics of family size, family poverty

\section{Background}

According to Hardman, Egan and Drew (2016), parents have largely failed in terms of developing integrated family plans. Such family plans are useful especially in enabling parents pass values, skills, and experience to their children. Parents fall short in terms of preparing their children for management of such children's own current and future wealth. Most prominently, parents are accused of failure to develop and to share their dreams and visions with their children [Reeves, 2017]. Neither have they taken up their role in honing their children's dreams in ways that the personal and collective success or synergy between such children may be actualized. All these and more accusations have been levelled against parents. However, key questions still linger: are parents wholesomely to blame for all these lapses? Has there been meaningful exertion anywhere in the world that builds a clear understanding among parents regarding the importance of developing integrated family plans? Has anyone come out to advance a thought that there may exist planning of families beyond "family planning" as defined today? 
Planning is widely considered a reserve for organizations [Schmieder, 2014]. An Internet search for the term "family planning," reveals it as the practice of controlling the number of children in a family and the intervals between their births. Although this definition silently appreciates availability and consumption of resources, family planning as a discipline offers a very weak connection to these factors beyond birth control variables. For example, most job openings for family planning experts or trainers will require that applicants are qualified in nursing, public health, medicine, surgery, midwifery or related fields. Conspicuously, there is no requirement for any form of qualification in strategic management, strategic planning or management generally.

It is a considered opinion that family planning should be a more encompassing concept than it currently is. Rao (2004) asserted that family planning as a concept was reshaped by the desire of nations to control population growth rather than a genuine vouch to popularize reproductive health, or sincere desire to promote actual planning for families (p. 15). In other words, masses were convinced that by simply controlling the number and spacing of children, families were being effectively planned. In the light of this historical misconception, it is important for modern career and discipline experts to re-assess the disciplinary content and housing of family planning. It would be a serious disservice to future generations, if family planning continued to wallow in the disciplinary oblivion. Invoking control on the number of children and spacing thereof cannot happen in isolation. Without sounding demeaning to the role of family planning as is currently regarded, planning the number, timing and spacing between children remains a much smaller, and indeed a tail-end component that can only happen after strategic visioning and planning of a family. Bolland (2017) articulates that strategic planning should encompass developing of specific short-term tactics that will cumulatively work towards a long-term, direction laid down. In this light, planning of the number of children and spacing thereof should be considered a tactical, short-term component towards achieving the long- term, family goals and strategic dreams.

\section{Strategic Success}

In order to develop strategic success within a family context, the following aspects must be put under very accurate reflection; first there should be creation of family awareness on strategic planning [Young, 2016]. Under this step, an encompassing awareness is created within a family and all the involved stakeholders. This is followed by formulation of family vision and mission [Davis, 2015]. A family vision is a brief statement on where the family intends to go strategically or in the long run. A mission statement on the other hand states how the family intends to navigate to the envisioned goal or to the stated vision [Hughes, 2010]. After 
developing vision and mission statements, family situation analysis and gap analysis have to be crafted. A situation analysis focuses on strengths and weaknesses of a family which are internal factors, and opportunities and threats which are external factors [Shams \& Lane, 2016]. A family that achieves strategic success is that which has overcome its weaknesses, leveraged on its strengths, remained vigilant against its external threats and effectively plugged into available opportunities for a sustainable (long-term) family strategic advantage.

Gap analysis on the other hand is an algorithm of the benefits brought about by designing and implementing a family strategy as opposed to the situation if the strategy would not have been executed. A strategy that passes the test of gap analysis is good for implementation [Partridge \& Sinclair-Hunt, 2005]. Family strategic implementation and strategic control have to be properly and carefully actualized for a family strategy to be successful. Strategic implementation within a family includes sharing responsibilities among family members with a goal of attaining synergistic advantage. This may also involve ensuring that all major and minor tasks are perfectly performed in the laid down manner within the set time. Strategic control entails among other undertakings, monitoring and evaluation of a family's short-term or operational progression in the light of the strategic dreams laid down. Family strategic planning is a cyclic movement where implementation and strategic control (at the end of the strategic cycle) empower newer, more improved formulation (at the beginning of the next cycle). At this point, important questions arise: are there family strategies that could be formulated by one generation and implemented by another? If it happened this way, would it be unfair for the newer generation to simply implement what it never formulated? How does a family monitor and evaluate cross-generational family strategy? Also, we need to remember, the older generations might not be alive to sell the strategic vision to the younger generations. How does the cross-generational family strategy earn the buy-in of the newer generations?

\section{The Irony}

The concepts and emerging issues articulated above may be heavy strategic or management concepts especially in the hands of a family planning expert as is currently widely known. The term "family planning" has been largely used as a euphemism for "utilization of contraception". Rather, many people using the term "family planning" refer to "contraceptive use" rather than the actual planning of families or the real designing of the overarching family strategy [Parry, 2013]. Around the world, unmarried, or even adolescent "couples" involved in sexual activity, could visit family planning experts just to seek advice regarding the best options for contraceptive use. Such couples may not be interested in any real planning of families. 
They have no families in the first place. This intensifies the question as to whether the concept of family planning as known today is inaccurate. Besides, there should be a global discussion regarding refacing, restructuring and implementation of the accurate concept of planning of families as it should be. However, the emerging observation is that planning of families as it ought to be, should be considered for housing under the strategic planning or management discipline rather than under the healthcare discipline as it is today. Disciplinary experts need to also interrogate the historical and conceptual basis upon which the healthcare world found itself operationalizing a concept meant to fall under a different disciplinary environment.

\section{A Family as a Going Concern}

In support of the larger concept of family strategic planning, it is important to note that families are organizations in themselves. They may be equated to competitive units just like businesses. However, due to the generational continuity factor, families are a more stable going concern as compared to businesses. Rather, a family's future existence is more guaranteed through reproduction, than the future existence of a business or an organization is guaranteed through succession planning. This calls for better consideration of strategic planning components among families.

\section{A Family as an Economic and Wealth Concern}

From an economics viewpoint, just like individuals and firms, families (referred to as households in economics) continually compete for scarce resources which can be depleted or even made extinct [Fox, 2017]. This then introduces a competitive characteristic among families or households. The gain on a family will generally imply lose on the side of another, holding other factors constant [McEachern, 2017]. The injection of competition into the family matrix automatically implies the need for strategy, or more accurately, competitive strategy. It is the opinion of the author that economic failure among nations, especially African nations, could be largely a complex of failure to reconsider households as a foundation for economic planning. It is no surprise that in evaluating economic growth, families are commonly considered units of consumption rather than units of production.

When considering, cross generational family businesses and wealth, and especially where large financial investments are involved, family strategy shows up yet again as an imperative component of successful business strategy and wealth management strategy. Wealth management across generations calls for robust succession planning, vibrant mentorship and family leadership strategy [Edadayo, Kensiro \& Fatunmbi, 2017], which are all subsets of family 
strategy. Also, the dynamic interplay between family leadership and family business leadership, calls for family strategy as a critical strategic lubricant. Talking of a strategic lubricant resolves the arising questions as to how a family could identify and even install family business leaders from within its membership, without causing internal bitterness, undue resentment or avoidable disharmony.

\section{Family Support Systems and Economic Value}

A support system is a network of people or organizations who may offer support to an individual or a group of people [Steinmetz, 2013]. Support systems may impact many areas of life including physical, education, workplace, business, career, spiritual life, emotional matters and so forth. Family support offers the most basic influence in the life of an individual. It is very critical especially at the formative phase of life. Research has demonstrated that individuals who fail to receive this kind of support in early childhood, are inclined to end up becoming social, emotional and behavioral misfits [Shaefer, 2008]. On the flip side, families with good support systems have propensity to create social, emotional, moral and behavioral fits and synergies that may result in economic value. A central characteristic of such families include tendency to share a higher sense of accountability [Sellnow, Verderber, \& Verderber, 2018]. Members are cognizant of their decisions and actions and are ready to bear consequences thereof. This works even better when a family is founded on clear and robust family values.

Besides the accountability factor, when family members are genuinely supportive of each other, there is a higher chance for mentorship in enterprise building. Family enterprises have a higher success rate where a good support system is in place. Such a family's support system becomes the core competitive advantage within the family business. One other immense advantage is a lasting legacy [Athwal, 2017]. Under this perspective, knowledge and competitive business secrets are retained in the family but get passed down from a generation to another. Mistakes cannot be repeated as experiences and gaps of the outgoing leaders are put together into worthy lessons that are passed down from one to the next generation of leaders.

\section{The Family Economy}

The term "family economy" is used as a means of describing a family as an economic unit. Key economic concepts are applied within this concept including production, division of labor, distribution, and decision making, as bases of analyzing the family unit [Rosenzweig \& Stark, 1997]. Ancient times saw families at the center of macroeconomic decisions. Some of the key advantages of putting families at the center of economic decisions included the synergistic 
economic leverage within families. Each member knew their economic role and had to play it well, firstly under the command of obligation and subsequently as their vocation. Moreover, families were seen as multi-generational producers created through the order of specialization.

Generally speaking, the wake of post-industrial society brought key changes to the global economy. Especially in Europe, service rendering overtook manufacturing as the most profitable economic venture. Partly, this was because of industrial and innovation explosion which lead to a new production economy [McAdams, 2015]. For example, farming could be done with less labor because of mechanization. Also, more effective chemicals were used to control crop pests further reducing labor requirement. Large-scale manufacturing and mass production became the order of the day. This change also affected the very core of the concept of family itself. Whereas more children were earlier on seen to be an economic asset, the post-industrial society adopted a capitalistic view that considered children a liability. Indeed, children were considered a cost [Ballantine \& Roberts, 2011]. In the same manner, a family was considered a unit of consumption (a cost) rather than a unit of production (a resource).

In the recent times, there are few studies done to establish interactions between family variables. It is a considered opinion that it is time contemporary researchers in economic and social variables revisited the paradigm of family economy, to establish the interactions thereof as a possible solution to the question of economic growth. Areas of focus may include; economics of marriage, economics of relationships, family production, income, expenditure and/or consumption dynamics, economics of family size and family poverty dynamics among other variables.

\section{Success Stories of Family Strategy}

Out of ingeniously thought out family strategies, strong, globally renowned, family-owned multinational partnership powerhouses have emerged. A good example of such successes is the Roche Company of Switzerland, largely controlled by the Hoffmann-Oeri family [Glattfelder, 2013]. Roche manufactures some of the best cancer drugs in the world today, with a market capitalization of US\$254 billion. Samsung Electronics of South Korea is another family success story. Lee Kun-Hee reengineered his father's business, Samsung Group, into a multinational company. He is currently the chairman of Samsung Electronics. His son Jay Lee is the vice chairman. While his daughters Boo-Jin and Seo-Hyun both hold senior strategic positions within the company [Kim, 2016].

Considering some of the extreme instances of cross generational family strategies, the experience of the Rothschild family comes to the forefront. The story of Rothschild empire 
begins in the 1760s when Mayer Amschel Rothschild (1744-1812) established a banking investment in Frankfurt, in Germany. Rothschild's strategic objective was to have each of his five children establish a banking venture in the cities of Frankfurt, Naples, Vienna, Paris, and London. Throughout the 1800s, Rothschild's strategic objectives were realized, and his five children's investments were successful long after his death. Better still; the five children did not simply stick with their father's vision. Instead, they injected their own strategic dreams into the original vision their father had. Today, despite some conflicting theories and varying opinions regarding the historical legitimacy of their investments and strategic decisions, Rothschild holdings are an icon of family strategic success. They hold efficacious investments across industries such as financial services, real estate, mining and energy among others [Kearns, 2013]. It may be anybody's guess that the longer end of the story of the Rothschild family is yet to be written by its future generations.

\section{Conclusion}

The purpose of this conceptual position is to introduce a discourse regarding the disciplinary housing of family planning as a professional concept. This paper proposes that "family planning" as is currently perceived, be renamed to assume its due scope under healthcare. This paper further suggests that planning for families as proposed, be housed under management or more specifically, under strategic management. However, the most robust term proposed is "family strategic planning" rather than "planning of families" or "family planning."

\section{References:}

1. Athwal, R. (2017). Unleash your Family Business DNA: Building a Family Legacy that Lasts Generations. New York: RTS Books.

2. Ballantine, J. H., \& Roberts, K. A. (2011). Our Social World: Condensed Version. Thousand Oaks: Pine Forge Press.

3. Bøås, M., \& McNeill, D. (2004). Global Institutions and Development: Framing the World? London: Routledge.

4. Bolland, E. J. (2017). Comprehensive Strategic Management: A Guide for Students, Insight for Managers. Bingley: Emerald Publishing Limited. https://doi.org/10.1108/9781787142244

5. Davies, J. A. (2015). Integrated Strategic Planning for the Family Business System Planning for Growth, Unity and Continuity. Available from https://cfeg.com/eBooks/ CIFE_Article_Integrated $\% 20$ Strategic $\% 20$ Planning $\% 20$ for $\% 20$ the $\% 20$ Family $\% 20$ Business\%20System.pdf. Accessed on 30th October 2017. 
6. Ededayo, S. O., Kesinro, O. R., \& Fatunmbi, O. M. (2017). Succession Mentoring and Sustainability of Family-Owned Business in Lagos and Ogun States, Nigeria. The International Journal of Business Management, 5(3), 27-32.

7. Fox, R. A. (2017). The Wiley Handbook of School Choice. Oxford: John Wiley \& Sons. https://doi.org/10.1002/9781119082361

8. Glattfelder, J. (2013). Decoding Complexity: Uncovering Patterns in Economic Networks. New York: Springer Heidelberg. https://doi.org/10.1007/978-3-642-33424-5

9. Hardman, M., Egan, W., \& Drew, C. J. (2016). Human Exceptionality: School, Community, and Family. Boston: Cengage Learning.

10. Hughes, J. E. (2010). Family Wealth: Keeping It in the Family - How Family Members and Their Advisers Preserve Human Intelectual, and Financial Assets for Generations. New York: Bloomberg Press.

11. Kearns, R. (2014). Step Inside the Truth. Bloomington: Authorhouse UK Limited.

12. Kim, C. (2016). Samsung, Media Empire and Family: A Power Web.

New York: Routledge - Tailor \& Francis Group. https://doi.org/10.4324/9781315669045

13. McAdams, J. (2015). The New Class in Post-Industrial Society. New York: Palgrave Macmillan. https://doi.org/10.1057/9781137515414

14. McEachern, W. A. (2017). Econ Micro. Boston: Cengage Learning.

15. Parry, M. (2013). Broadcasting Birth Control: Mass Media and Family Planning. London: Rutgers University Press.

16. Partridge, L., \& Sinclair-Hunt, M. (2005). Strategic Management. Cambridge: Select Knowledge Limited.

17. Rao, M. (2004). From Population Control To Reproductive Health: Malthusian Arithmetic. New Delhi: Sage Publications.

18. Reeves, R. V. (2017). Dream Hoarders: How the American Upper Middle Class Is Leaving Everyone Else in the Dust, why that is a Problem, and what to do about it. Washington, D. C. : The Brookings Institution.

19. Rosenzweig, M. R., \& Stark, O. (1997). Handbook of Population and Family Economics Volume 1, Part 1. San Diego: Elsevier Inc. https://doi.org/10.1016/S1574-003X(97)80018-9

20. Schmieder, J. (2014). Innovation in the Family Business: Succeeding Through Generations. New York: Palgrave McMillan. https://doi.org/10.1057/9781137386243 